\title{
Üniversiteli Sporcuların Psikolojik Dayanıklılık Düzeylerinin İncelenmesi ${ }^{1}$
}

\author{
Tamer KARADEMIR \\ Doç. Dr., Kahramanmaraş Sütçü İmam Üniversitesi, \\ Beden Eğitimi Spor Yüksekokulu \\ tamer.karademir@hotmail.com \\ Orcid ID: https://orcid.org/0000-0003-3244-0767

\section{Mahmut AÇAK} \\ Doç. Dr., İnönü Üniversitesi, Spor Bilimleri Fakültesi \\ m.acak@hotmail.com \\ Orcid ID: https://orcid.org/0000-0002-2843-4834
}

\begin{abstract}
Öz
$\mathrm{Bu}$ çalışma üniversitede eğitim öğrenim gören sporcu öğrencilerin ele alınan bazı değişkenlere göre psikolojik dayanıklılık düzeylerinin nasıl şekillendiğini belirlemek amacıyla yapılmıştır. Çalışma Kahramanmaraş Sütçü İmam Üniversitesinde 220 öğrenci üzerinde yürütülmüştür. Verilerin toplanmasında kişisel bilgi formu ve Yetişkinler için Psikolojik Dayanıklılık Ölçeği'nin kısa formu kullanılmıştır. Araştırma grubunun cinsiyet değişkenine göre psikolojik dayanıklılık düzeylerinde erkekler lehine fark olduğu tespit edilmiştir. Yaş değişkenine göre istatistiksel olarak anlamlı fark olduğu belirlenmiştir. $\mathrm{Bu}$ çalışma sonucunda; psikolojik dayanıklılık düzeylerinin cinsiyete göre farklılık gösterdiği ve erkeklerin psikolojik dayanıklılık düzeylerinin daha yüksek olduğu görülmüştür. Yaş değişkeninin psikolojik dayanıklılık düzeyini belirlemede etkili olduğu ve 18-21 yaş grubundakilerin aldığ puan ortalamalarının daha düşük olduğu görülmüştür. Ayrıca gelir durumu yüksek olan öğrencilerin psikolojik dayanıklılık düzeylerinin de yüksek olduğu bulunmuştur.
\end{abstract}

Anahtar Kelimeler: Spor, Psikolojik Dayanıklılık, Eğitim.

\footnotetext{
${ }^{1}$ Makale Geliş/Kabul Tarihi: 16.05.2019 / 08.08.2019

Künye Bilgisi: Karademir, T., Açak, M. (2019). Üniversiteli Sporcuların Psikolojik Dayanıllllk Düzeylerinin İncelenmesi. Kahramanmaraş Sütçü İmam Üniversitesi Sosyal Bilimler Dergisi, 16 (2), 803-816. DOI: 10.33437/ksusbd.566577
} 


\title{
Investigating the Psychological Endurance Levels of University Athletes
}

\begin{abstract}
This study was conducted with the aim of determining how the psychological endurance levels of students involved in sports at university are shaped based on some variables that are discussed here. For this study was carried out with a total of 220 students at Kahramanmaras Sutcu Imam University. The data were collected by a personal information form and the short form of the Psychological Endurance Scale for Adults. There was a significant difference in the psychological endurance levels in the sample in the favor of the males. There was also a significant difference based on age. As a result of this study, it was observed that levels of psychological endurance differed based on gender and the males had higher levels of endurance. It was seen that the variable of age was effective in predicting the levels of psychological endurance, and the scores of those in the age group of 18-21 were lower. It was observed that the students in the sample with higher income levels also had higher psychological endurance levels.
\end{abstract}

Keywords: Sports, Psychological Endurance, Education.

\section{GİRIŞ}

Sosyo-kültürel bir varlık olan insan, gereksinimlerinin karşılandığı doğal çevresi ve kendine özgü kişiliğini geliştirdiği sosyal çevresi ile bütünleşerek yaşamını sürdürmektedir. Çevresine uyum sağlama çabası içinde olan insan, yaşamında sevdiği birini kaybetmesi, işinden atılması, ölümcül bir hastalığa yakalanması, ailesinin dağılması gibi bir takım sorunlarla karşılaşmaktadır. Söz konusu bu olaylar karşısında eğer insan kendini koruyacak yeterli donanıma sahip değilse, sorunlar karşısında kendini güçsüz hissetmekte, psikolojik ve fiziksel rahatsızlıklar yaşamaktadır. Öte yandan öyle insanlar da vardır ki, en büyük felaketler karşısında bile yaşamlarını sürdürmeye devam ederler ve kendileri için gerekli olan enerji ve gücü üretirler. Sahip oldukları yaşam becerileri ile yaşanan sorunlar karşısında ayakta kalabilmeyi başaran bu bireyler, sağlıklı olmaya yönelmiş, bireysel amaçlara sahip ve daha anlamlı yaşam geçirme hedefi olan bireylerdir (Terzi, 2008:2).

İnsanın sosyal ilişki kurma gereksinimi olduğu için; içinde yaşadığı toplumda diğer insanlarla ilişki kurmaya, bu ilişkileri devam ettirmeye çalışır. Bu amaçla hayatında yeni düzenlemeler yapar ya da var olan düzenlemelere uyar (Kayacı, 
2014:2). Üniversite dönemi, gençlerin gelişimsel olarak kimlik ve bağımsızlık kazanma çabalarına devam ettiği, üniversite yaşamının beraberinde getirdiği sorunlarla mücadele edilmeye çalışılan ve ilişkilerin çok hızlı değişim gösterdiğgi erişkinliğe geçiş dönemidir. Üniversitede okuma şansı elde edenler, üniversiteyi kazanma sevincinin yanı sıra; aileden ayrılma, yeni çevre ve arkadaş edinme, yalnız kalma korkusu, ekonomik güçlükler, yurt hayatına alışma, gelecekteki mesleği ve çalışma hayatı ile ilgili kaygı gibi birçok sorunla karşılaşırlar. Gençler bu problemleri aşmaya çalışırlarken çeşitli kaynaklardan gelen stres ve zorlanmalara maruz kalırlar (Güngörmüş vd., 2015:9). Öğrenciler maruz kaldıkları stres ve zorlanmalar karşısında kendini koruyacak yeterli donanıma sahip değillerse, kendilerini güçsüz hissedebilirler, psikolojik ve fiziksel rahatsızlıklar yaşayabilirler. Stres verici yaşam olayları karşısında öğrencilerin kendisini çabuk toparlanmasını sağlayan en önemli özelliklerinden birisi psikolojik dayanıklılıktır. Psikolojik dayanıklılık, kişinin engel, belirsizlik ve benzeri birçok olumsuz durumla baş etme ve başarılı olma yeteneğidir. Kişi psikolojik olarak dayanıklıysa, gelişim dönemi özelliklerine uygun olarak gelişimini sürdürecek, kendisinden beklenen görevleri yerine getirecek, ilişkilerini sağlıklı bir biçimde devam ettirecek ve okul yaşamında başarılı bir birey olacaktır (Terzi, 2008:11).

Psikolojik dayanıklılık genel olarak bir başarı veya uyum sağlama sürecini ifade eder. Bu çerçevede bir travma, bir tehdit, bir trajedi veya ailesel ve ilişkisel sıkıntılar, ciddi sağlık problemleri, işyeri ve parasal sorunlar gibi önemli stres kaynaklarına karşı, psikolojik dayanıklılık kişinin uyum sağlama süreci olarak görülmektedir. Diğer açıdan psikolojik dayanıklılık, zor yaşamsal tecrübeler karşısında kişinin kendisini toparlama gücü veya değişimin ya da felâketlerin başarılı biçimde üstesinden gelme yeteneği olarak da tanımlanmaktadır (Basım ve Çetin, 2011:105). Psikolojik dayanıklılık, kişisel nitelikleri ifade eden bir kavramdır ancak dış faktörlerden etkilenebilmektedir. Maddi ve Khoshaba (1994), aile ortamının psikolojik dayanıklılığın oluşmasında etkili olduğunu belirterek, ailelerin özellikle, çocukların çevrelerindeki değişimleri firsat olarak algılamalarını sağlayarak psikolojik dayanıklılığı desteklediklerini ifade etmişlerdir.

Psikolojik dayanıklılık ilk bakışta stresin olumsuz etkilerini azaltan ve uyumluluğu destekleyen bir kişilik özelliği olarak görülmektedir. Bu açıdan bazı araştırmalar genetik özelliklere odaklanarak bazı kişilerin dayanıklı olarak doğduklarını öne sürmektedir. Fakat yapılan çalışmalar psikolojik dayanıklılı̆̆ın öğrenilebilir bir kişisel özellik olduğunu da ortaya çıkarmıştır. Psikolojik dayanıklılık, karşı karşıya kalınan gerçekler karşısında algılanarak fark edilen, öğrenilen ve gelişimsel süreç içeren bir olgu olmaktadır (Basım ve Çetin, 2011:105). 
İnsanların yaşama bakışları, yaşama ait beklentileri ve bunun karşılanma düzeylerinin neden olduğu psikolojik bir özellik olan yaşam doyumunun, çalışanların örgütsel yaşamına etkileri bulunmaktadır. Yaşam doyumu, bir insanın ne istediği ve bunu sahip oldukları ile karşılaştırmasıyla elde edilen durum ve bu durumu algılamasıdır. Başka bir deyişle yaşam doyumu, bireyin yaşama dair beklentileri ve bunların karşılanma düzeyi ile ortaya çıan durumdur; mutluluk, moral vb. gibi özelliklere bağlı iyi olma halini ifade eder (Özer ve Karabulut, 2003:73).

Üniversitelerde öğrenim gören gençlerin psiko-sosyal özelliklerinin iyi bilinmesi, sorunlarının incelenerek sorun kaynaklarının anlaşılması ve elde edilen bilgilere bağlı olarak öğrencilerin uyumlarını artırıcı yaklaşımlar geliştirilmesine gereksinim vardır (Güngörmüş vd., 2015:11). Bu çalışma da üniversite eğitimi alan sporcu öğrencilerin ele alınan bazı değişkenlere göre psikolojik dayanıklılık düzeylerinin nasıl şekillendiğini belirlemek amacıyla yapılmıştır.

\section{YÖNTEM}

\section{Çalıșma Grubu}

Bu araştırma, 2017-2018eğitim ve öğretim y1lında Kahramanmaraş Sütçü İmam Üniversitesinin farklı fakülte ve yüksekokullarında eğitim gören ve spor yapan, yaşları 18 ile 27 arasında değişen ve $21,37 \pm 2,73$ ortalama yaşa sahip 80 bayan 140 erkek olmak üzere toplam 220 öğrenci üzerinde yürütülmüştür. Verilerin toplanmasında kişisel bilgi formu ve Yetişkinler için Psikolojik Dayanıklılık Ölçeği'nin kısa formu kullanılmıştır.

\section{Veri Toplama Aracı}

Kişisel Bilgi Formu: Literatür bilgileri doğrultusunda araştırmacı tarafindan hazırlanan ve katılımcıların yaş, cinsiyet, gelir düzeyi, fakülte ve spor türünü içeren 5 sorudan oluşmaktadır. Çalışmada ölçeğin Smith vd., (2008) tarafından geliştirilen Akın vd., (2014) ve daha sonra Doğan (2015) tarafindan Türkçeye uyarlanan ve benzer sonuçlar bulunan Kısa psikolojik dayanıklılık ölçeği kullanılmıştır. Kısa Psikolojik Dayanıklılık Ölçeği 6 maddeden oluşan 5'li (hiç katılmıyorum $=1$, tamamen katıllyorum $=5$ ) likert tipi ve tek boyutlu bir ölçektir. Ölçekte 2, 4, 6. maddeler ters kodlanmaktadır. Ölçeğin ters kodlanan maddeleri ters kodlandıktan sonra tüm maddelerinden alınan puanlar toplanarak psikolojik dayanıklılık puanı elde edilmektedir ve ölçekten alınabilecek olası puan aralığı 6 ile 30 arasında değişmektedir. Ölçekten alınan yüksek puanlar psikolojik dayanıklılı̆̆ın yüksek olduğunu göstermektedir (Akın vd., 2014).

\section{Verilerin Analizi}


Çalışma grubundan elde edilen veriler SPSS paket programı kullanılarak analiz edilmiştir. Verilere uygun analiz türünü belirlemek amacı ile öncelikle normal dağılıp dağılmadıklarına Kolmogorov Simirnov testi ile bakılmış sonrasında verilerin homojen olup olmadıkları test edilmiştir. Verilerin homojen olması ve normal dağılım göstermesi parametrik testleri kullanmamızı sağlamıştır. Bunlar, bağımsız değişken olarak ele alınan ve ikili grup karşılaştırmalarında independent sample t-testi ve ikiden fazla grup karşılaştırmaları için tek yönlü varyans analizidir (ANOVA). Analiz sonuçlarında fark çıktığında bu farkın kaynağını bulmak amacıyla LSD testi kullanılmıştır. Araştırmada istatistiksel anlamlılık derecesi $\mathrm{p}<0.05$ olarak kabul edilmiştir.

\section{BULGULAR}

Araştırma grubunun demografik bilgileri ve psikolojik dayanıklılık ölçeğinden elde veriler bağımsız değişkenlere bağlı olarak istatistiksel analizleri yapılarak aşağıda tablolar halinde sunulmuştur.

Tablo 1. Araştırma grubunun demografik dağılımları

\begin{tabular}{lcc}
\hline & $\mathbf{n}$ & $\mathbf{\%}$ \\
\hline Cinsiyet & 140 & \\
\hline Erkek & 80 & 36,6 \\
\hline Bayan & & \\
\hline Yaş & 82 & 37,3 \\
\hline$<21$ & 68 & 30,9 \\
\hline $22-24$ & 70 & 31,8 \\
\hline 25 ve üzeri & & \\
\hline Gelir Düzeyi & 48 & 21,8 \\
\hline Kötü & 138 & 62,8 \\
\hline Orta & 34 & 15,4 \\
\hline Iyi & & 36,4 \\
\hline Fakülte & 80 & 20,4 \\
\hline BESYO & 45 & 18,2 \\
\hline i.i.B.F & 40 & 25,0 \\
\hline M.M.F & 55 & 72,8 \\
\hline Diğer (Fen Ed.-M.Y.O'ları) & & 27,2 \\
\hline Spor türü & 160 & 100,0 \\
\hline Takım sporu & 60 & \\
\hline Bireysel spor & 220 & \\
\hline Toplam & & \\
\hline
\end{tabular}


Tablo 1'e göre araştırma grubunun \%63,6'sının erkek, \%36,4'ünün bayan olduğu, \%72,8'inin takım sporları, \%27,2'sinin bireysel sporlar ile uğraştığı, \%21,8'inin gelir düzeyinin kötü, \%62,8'inin orta düzey ve \%15,4'ünün yüksek gelire sahip olduğu tespit edilmiştir.

Tablo 2. Araştırma grubunun cinsiyet değişkenine göre analiz sonuçları (t-test)

\begin{tabular}{|c|c|c|c|c|c|c|}
\hline \multicolumn{2}{|l|}{ Cinsiyet } & $\mathrm{n}$ & Mean & SD & $\mathrm{t}$ & $\mathrm{p}$ \\
\hline Psikolojik & Erkek & 140 & 22,03 & 3,41 & \multirow{2}{*}{2,855} & \multirow{2}{*}{,005* } \\
\hline Dayanıklılık & Bayan & 80 & 20,11 & 3,97 & & \\
\hline
\end{tabular}
${ }^{*} \mathrm{p}<0.05$

Tablo 2'ye göre araştırma grubunun cinsiyet değişkenine göre psikolojik dayanıklılık düzeyleri arasında erkekler lehine istatistiksel olarak anlamlı fark olduğu tespit edilmiştir $(\mathrm{t}=2,855 ; \mathrm{p}<0,05)$.

Tablo 3. Araştırma grubunun yaş değişkenine göre analiz sonuçları (ANOVA)

\begin{tabular}{|c|c|c|c|c|c|c|c|}
\hline Yaş & & $\mathrm{n}$ & Mean & SD & $\mathrm{F}$ & $\mathrm{p}$ & $\begin{array}{l}\text { Fark } \\
\text { LSD } \\
\end{array}$ \\
\hline \multirow{3}{*}{$\begin{array}{l}\text { Psikolojik } \\
\text { Dayanıklılık }\end{array}$} & $<21$ & 82 & 19,45 & 4,32 & \multirow{3}{*}{3,423} & \multirow{3}{*}{,027* } & \multirow{3}{*}{$1<2$} \\
\hline & $22-24$ & 68 & 22,25 & 4,64 & & & \\
\hline & 25 ve üzeri & 70 & 21,10 & 5,15 & & & \\
\hline
\end{tabular}

Tablo 3'e göre araştırma grubunun yaş değişkenine göre psikolojik dayanıklılık düzeylerinde istatistiksel olarak anlamlı fark olduğu tespit edilmiştir $\left(\mathrm{F}_{(2,217)}=3,423 ; \mathrm{p}<0,05\right)$. Farkın kaynağı bulmak için yapılan testte bu farkın 21 ve daha küçük yaş grubu ile 22-24 yaş grubundan kaynaklandığı belirlenmiştir.

Tablo 4. Araştırma grubunun fakülte değişkenine göre analiz sonuçları (ANOVA)

\begin{tabular}{llccccc}
\hline Fakülte & & $\mathrm{n}$ & Mean & $\mathrm{SD}$ & $\mathrm{F}$ & $\mathrm{p}$ \\
\hline \multirow{3}{*}{$\begin{array}{l}\text { Psikolojik } \\
\text { Dayanıkl1lık }\end{array}$} & BESYO & 80 & 21,01 & 4,66 & & \\
\cline { 2 - 5 } & İ.̇̇.B.F & 45 & 21,12 & 4,40 & & \\
\cline { 2 - 5 } & M.M.F & 40 & 21,57 & 4,27 & & \multirow{2}{*}{340} \\
\cline { 2 - 5 } & Diğer & 55 & 20,98 & 5,11 & & \\
\hline
\end{tabular}


Tablo 4'e göre araştırma grubunun fakülte değişkenine göre psikolojik dayanıklılık düzeylerinde istatistiksel olarak anlamlı fark olmadığı belirlenmiştir $\left(\mathrm{F}_{(3,216)}=1,225 ; \mathrm{p}>0,05\right)$.

Tablo 5. Araştırma grubunun spor türü değişkenine göre analiz sonuçları (t-test)

\begin{tabular}{llccccc}
\hline \multicolumn{1}{c}{ Spor türü } & & $\mathrm{n}$ & Mean & $\mathrm{SD}$ & $\mathrm{t}$ & $\mathrm{p}$ \\
\hline Psikolojik & Takım sporu & 160 & 20,48 & 4,15 & & \\
\cline { 2 - 5 } Dayanıkl11ık & Bireysel spor & 60 & 21,99 & 4,33 & & \multirow{2}{*}{$005^{*}$} \\
\hline${ }^{*} \mathrm{p}<0.05$ & & & & & &
\end{tabular}

Tablo 5'e göre araştırma grubunun spor türü değişkenine göre psikolojik dayanıklılık düzeylerinde bireysel spor yapanlar lehine istatistiksel olarak anlamlı fark olduğu tespit edilmiştir $(\mathrm{t}=3,441 ; \mathrm{p}<0,05)$.

Tablo 6. Araştırma grubunun gelir düzeyi değişkenine göre analiz sonuçları (ANOVA)

\begin{tabular}{lccccccc}
\hline Gelir Düzeyi & & $\mathrm{n}$ & Mean & SD & F & p & $\begin{array}{r}\text { Fark } \\
\text { LSD }\end{array}$ \\
\hline Psikolojik & 1.Kötü & 48 & 19,45 & 4,22 & & & \\
\cline { 2 - 5 } Dayanıkl1lık & 2.Orta & 138 & 21,01 & 4,57 & 3,588 & \multirow{2}{*}{, $011^{*}$} & $1<3$ \\
\cline { 2 - 6 } & 3.İyi & 34 & 22,12 & 5,08 & & & \\
\hline
\end{tabular}

$* \mathrm{p}<0.05$

Tablo 6'ya göre araştırma grubunun gelir düzeyi değişkenine göre psikolojik dayanıklılık düzeylerinde gelir düzeyi iyi olanlar lehine istatistiksel olarak anlamlı fark olduğu tespit edilmiştir $\left(\mathrm{F}_{(2,217)}=3,588 ; \mathrm{p}<0,05\right)$.

\section{TARTIȘMA}

$\mathrm{Bu}$ araştırmada üniversitenin farklı fakülte ve yüksekokullarında öğrenim gören sporcu öğrencilerin psikolojik dayanıklılıklarının ne düzeyde şekillendiği araştırılmıştır. Buna göre; Araştırma grubunun cinsiyet değişkenine göre psikolojik dayanıklılık düzeylerinin erkekler lehine istatistiksel olarak anlamlı fark olduğu tespit edilmiştir (Tablo 2.). Psikolojik dayanıklılık konusunda yapılan bazı çalışmalarda yaş, eğitim, cinsiyet ya da hizmet süresi gibi bazı kişisel özelliklerin bireylerin dayanıklılık düzeylerine etkisi araştırılmış (Crowley vd., 2003; Harrisson vd., 2002; Klag ve Bradley, 2004) ve birbiriyle çok da tutarlı olmayan sonuçlar elde edilmiştir. Yine literatürden edinilen bilgiler ışığında bazı 
çalışmalar kadınlar lehine (İlhan, 2017), bazı çalışmalar ise erkekler lehine anlamlı sonuçlara ulaşmışlardır (Solomon, 2015).

Kumar vd. (2016) tarafından yapılan araştırmada 72 elit kadın ve erkek voleybolcuların cinsiyet değişkenine göre psikolojik dayanıklılık düzeylerinin anlamlı farklılık göstermediği belirlenmiştir. Bu sonucun ortaya çıkmasının temelinde kadın ve erkek voleybolcuların benzer kondisyon seviyesine sahip olmalarının, sportif becerilerinin benzer düzeyde olmasının ya da benzer duygusal özelliklere sahip olmalarının yattığı belirtilmiştir. Bacanlı ve Sürücü (2006), Gazi Üniversitesi Eğitim Fakültesi’nde öğrenim gören 677 öğrencinin üniversiteye genel, sosyal ve akademik açılardan uyum düzeylerinin psikolojik dayanıklılık düzeylerine ve cinsiyetlerine göre farklılık oluşturup oluşturmadığını incelemişlerdir. Araştırma sonuçlarında ise cinsiyet değişkeni açısından bakıldığında erkek öğrencilerdeki üniversiteye uyum düzeylerinin, kız öğrencilerin üniversiteye uyum düzeylerinden anlamlı olarak yüksek olduğu sonucuna varılmıştır. İlhan (2017)'in yaptığ 1 araştırmaya göre ise egzersize katılan bireylerin psikolojik dayanıklılık düzeyleri cinsiyet değişkenine göre istatistiksel açıdan anlamlı farklılık göstermiştir ve kadın katılımcıların lehine yüksek olduğu bulunmuştur. Yapılan başka bir araştırmada da çalışmamızın bulgularını destekleyen sonuçlara ulaşılmış, 19-24 yaş aralığında bulunan kadın ve erkek futbolcuların psikolojik dayanıklılık ve kaygı düzeylerinin incelendiği araştırma sonucunda kadın futbolcular ile kıyaslandığı zaman erkek futbolcuların psikolojik dayanıklılık düzeylerinin daha yüksek olduğu tespit edilmiştir (Kumar, 2016). Benzer şekilde Khan vd., (2016) 50 kadın ve 50 erkek olmak üzere toplam 100 basketbolcunun psikolojik dayanıklılık düzeylerini cinsiyet değişkenine göre incelemiş ve kadın basketbolcular ile kıyaslandığı zaman erkek basketbolcuların psikolojik dayanıklılık düzeylerinin daha yüksek olduğu sonucuna ulaşı1mıştır.

Psikolojik dayanıklılığın, yüksek düzeyde olumsuz yaşantılara maruz kalan bireylerde gözlenen uyum yeteneği olduğu belirtilmekte ve normal gelişime sahip bireylerin sergilediği uyumdan farklılık gösterdiği vurgulanmaktadır (Vanderbilt-Adriance, 2001). Araştırma grubunda yer alanlar cinsiyet açısından değerlendirildiğinde, erkeklerin farklı psikolojik deneyim, zorlanma ve uyum sürecine maruz kaldıkları bunun da psikolojik dayanıklılık düzeylerine etki ettiği söylenebilir.

Araştırma grubunun yaş değişkenine göre psikolojik dayanıklılık düzeylerinde istatistiksel olarak anlamlı fark olduğu tespit edilmiştir. 22-24 yaş aralığında olanların 21 ve daha küçük yaş grubuna göre psikolojik dayanıklılık düzeylerinin daha yüksek olduğu görülmüştür (Tablo 3.). Psikolojik dayanıklılık üzerine yapılan araştırmalarda yaş değişkeni açısından bakıldığında farklı bulgulara rastlanmaktadır. Chan (2003) öğretmenler üzerinde yaptığı çalışmada yaş değişkeninin temel etkisinin anlamlı olmadığını, Harrison ve ark., (2002) 
yaşın psikolojik dayanıklılık üzerinde etkili olmadığını, Sezgin (2009) ise çalışmasında öğretmenlerin yaşına göre psikolojik dayanıklılık düzeyleri arasında anlamlı ilişki olmadığını belirtmektedir. Bunun yanı sıra çalışmamızla benzerlik gösteren ve yaş ilerledikçe psikolojik dayanıklılık düzeylerinde artış bulan çalışmalarda vardır (Kimhi, Goroshit, ve Eshel, 2013). Yaşın ilerlemesine bağlı olarak sporcuların müsabaka ve deneyimlerinin artmasına bağlı olarak psikolojik dayanıklılık düzeylerinde artış olması da beklenebilecek sonuçlar arasında görülmektedir (Bülbül, 2015).

Araştırma grubunun fakülte değişkenine göre psikolojik dayanıklılık düzeylerinde anlamlı fark görülmezken, yaptıkları spor türü değişkenine göre psikolojik dayanıklılık düzeylerinde bireysel spor yapanlar lehine anlamlı fark olduğu tespit edilmiştir (Tablo 4-5).

Literatürde konu ile ilgili farklı sonuçlara ulaşan çalışmalar görülmektedir. Reddy ve Berhanu (2016) tarafindan yapılan araştırmada farklı spor dalları ile ilgilenen sporcuların spor dalı değişkenine göre psikolojik dayanıklılık düzeylerinin karşılaştırılmıştır. Araştırmaya farklı üniversitelerde öğrenim gören 16 futbolcu, 11 basketbolcu ve 10 voleybolcu dahil edilmiş araştırmanın sonunda sporcuların psikolojik dayanıklılık ölçeğinden elde edilen toplam puanın ilgilenilen spor dallarına göre anlamlı farklılık gösterdiği sonucuna ulaşılmıştır. Solomon (2015) tarafından yapılan araştırmada farklı spor dalları ile ilgilenen, 2 yıl boyunca düzenli spor yapma alışkanlığ bulunan 174 sporcu katılmıştır. Araştırmanın sonunda sporcuların ilgilendikleri spor dallarına göre psikolojik dayanıklılık düzeylerinin istatistiksel açıdan anlamlı farklılık gösterdiği bulunmuştur. Elde edilen bulgulara göre en yüksek psikolojik dayanıklılık düzeyine basketbolcuların sahip olduğu, bunu sırasıyla kros, atıcılık, yüzme, tenis ve golf sporcularının takip ettiği belirlenmiştir. İlhan (2017) ise araştırmasında katılımcıların psikolojik dayanıklılık düzeylerinin ilgilendikleri spor türüne göre anlamlı farklılık göstermediğini, takım ve bireysel spor dalları ile ilgilenen bireylerin psikolojik dayanıklılıklarının benzerlik gösterdiğini ifade etmiştir. Ancak haftalık egzersiz sıklıklarına göre psikolojik dayanıklılık düzeylerinin anlamlı düzeyde farklılaştığını belirtmiştir.

Mevcut çalışmada takım sporu ile uğraşanlara göre bireysel sporla uğraşanların psikolojik dayanıklılıkları anlamlı olarak yüksek çıkmıştır. Bu sporcuların yaptıkları spor branşlarında kendi başlarına mücadele ve karşılaştıkları zorlukların üstesinden gelme çabasından kaynaklanmış olabilir. Ayrıca beden eğitimi, spor ve oyun etkinliklerine katılım insanların iç ve dış dünyalarını daha iyi tanımalarına (Artar, 2004), zihinsel ve bilişsel açıdan gelişimin desteklenmesine (Bailey, 2006) katkı sağlamaktadır. Ek olarak Nicholls vd., (2016) tarafindan yapılan araştırmada sporcularda antrenör 
davranışlarının da güdüsel iklim üzerinde etkili olduğu için bu durumun psikolojik dayanıklılık düzeyini de etkileyebileceği vurgulanmıştır.

Araştırma grubunun gelir düzeyi değişkenine göre psikolojik dayanıklılık düzeylerinde gelir düzeyi iyi olanlar lehine istatistiksel olarak anlamlı fark olduğu tespit edilmiştir (Tablo 6.). Aslında literatür bilgiler zor hayat şartları ile mücadelenin psikolojik dayanıklılık üzerinde etkili olduğunu belirtmektedir (Judkins ve Rind, 2005). Psikolojik dayanıklılık, olumsuz koşulların içerdiği tehlikelerden arınmayı ve uyumlu bir yaşam sergilemeyi sağlayan bir dayanma gücüne işaret etmektedir. Buna göre, bir olumsuz deneyim karşısında ortaya çıkan psikolojik dayanıklılığın gelecekte karşılaşılan başka olumsuz deneyimlerin üstesinden gelmeyi de kolaylaştırdığına dikkat çekilmektedir (Garmezy, 1993). Maddi ve Khoshaba (1999) sosyo-ekonomik düzeyde düşüklük gibi strese sebep olan vakalarla karşı karşıya kalmanın psikolojik dayanıklılık ve kişilik özelliğinin gelişmesinde etkin olduğunu ifade etmiştir. Bu anlamda yüksek psikolojik dayanıklılık düzeyine sahip olan bireyler, stresli yaşam olaylarıyla karşılaştıklarında problem çözme ve planlama gibi stratejilerden daha fazla yararlanarak kaçınma yönelimi yerine, psikolojik dayanıklılığa ve etkin baş etme becerilerine sahip olurlar (Klag ve Bradley, 2004). Ancak mevcut çalışmadaki gelir düzeyi iyi olanların psikolojik dayanıklılıklarının da yüksek çıkması, spora katılımın psikolojik yapı üzerindeki olumlu etkilerinin (Dishman vd., 2006; Babiss ve Gangwisch, 2009; Duman ve Kuru, 2010) bu duruma etki etmiş olabilmesi ile açıklanabilir.

Literatürde yer alan çeşitli araştırma bulguları spora katılımın psikolojik yapı üzerinde olumlu etkileri olduğunu göstermektedir (Dishman vd., 2006; Babiss ve Gangwisch, 2009; Duman ve Kuru, 2010). Salar, Hekim ve Tokgöz (2012) tarafından yapılan araştırmada 15-18 yaş grubunda bulunan takım ve bireysel spor dalları ile ilgilenen sporcuların psikolojik özellikleri incelenmiş, hem takım hem de bireysel spor dallar1 ile ilgilenen bireylerin kendilerini duygusal olarak iyi hissetme düzeylerinin benzerlik gösterdiği ve haftada en az 3-4 gün düzenli olarak spor yapan bireylerin kendilerini duygusal olarak çok iyi hissettikleri belirlenmiştir. Aynı çalışmada elde edilen sonuca göre genç bireylerin psikolojik sağlıklarının geliştirilmesinde hem takım hem de bireysel spor dallarına katılımın faydalı olacağ 1 belirtilmiştir. Bunun yanında spor etkinliklerine katılımın insanların iş yaşamında karşılaştıkları sorunlarla baş edebilecek gücü kendinde bulduğu, amaçsızlık ve monoton yaşam şartlarının ortaya çıkardığı kötümser psikolojik yapıyı ortadan kaldırdığı bilinmektedir (Küçük ve Koç, 2004). Şahin, Yetim ve Çelik'e (2012) göre fiziksel aktivite ve spor etkinliklerine katılım fiziksel dayanıklılığı arttırdığı için insanların zorluklara karşı mücadele gücünü geliştirmektedir.

\section{SONUÇ}


Üniversitenin farklı fakülte ve yüksekokullarında öğrenim gören sporcu öğrenciler üzerinde yürütülen bu çalışma sonucunda; psikolojik dayanıklılık düzeylerinin cinsiyete göre farklılık gösterdiği ve erkeklerin psikolojik dayanıklılık düzeylerinin daha yüksek olduğu görülmüştür. Yaş değişkenin psikolojik dayanıklılık düzeyini belirleme etkili olduğu ve daha küçük yaş grubundakilerin aldığı puan ortalamalarının daha düşük olduğu görülmüştür. Eğitim gördükleri fakülte değişkeninin psikolojik dayanıklılık düzeyine etki etmediği ancak öğrencilerin yapmış oldukları spor türünün psikolojik dayanıklılık düzeyini belirlemede etkili olduğu ve takım sporları ile uğraşanlara göre bireysel sporlarla uğraşan öğrencilerin daha yüksek psikolojik dayanıklılık düzeylerine sahip oldukları, yüksek gelir seviyesinde olanların ise kötü gelir düzeyine sahip olanlara göre psikolojik dayanıklılık düzeylerinin de yüksek olduğu sonucuna ulaşılmıştır.

Araştırmanın daha büyük örneklem grubu ve spor branşları üzerinde yapılması konu ile ilgili çalışma yapan araştırmacılara ş̧ık tutabilir. Antrenör ve spor eğitimcilerinin mevcut fiziksel antrenmanlarına ek olarak mental antrenman programları uygulamaları sporcuların psikolojik dayanıklılık ve psikolojik iyi olmaları üzerine olumlu etkiler sağlayabilir.

\section{KAYNAKÇA}

Akın Ahmet, Turan Mehmet-Emin, Sahranç Ümit, Akın Ümran ve Ercengiz Mustafa (2014), "Kısa Psikolojik Dayanıklılık Ölçeği Türkçe Formu'nun geçerlik ve güvenirliği”, III. Sakarya Eğitim Araştırmaları Kongresi, 12 Haziran 2014, Sakarya.

Artar, Müge (2004), Okul Öncesi Öğretmenlerinin Çocukların Oyun Hakkı'na İlişkin Tutumları, Türkiye'de Çocuk Oyunları: Araştırmalar. Bekir Onur, Neslihan Güney (Yayına Hazırlayan). Ankara: Ankara Üniversitesi Çocuk Kültürü Araştırma ve Uygulama Merkezi Yayınları.

Babiss, Lindsay A. ve Gangwisch, James E. (2009), “Sports Participation as a Protective Factor Against Depression and Suicidal İdeation İn Adolescents as Mediated By Self-Esteem And Social Support”, Journal of Developmental \& Behavioral Pediatrics, 30(5), ss. 376-384.

Bacanl1, Feride ve Sürücü, Mustafa (2006), “Üniversiteye Uyumun Psikolojik Dayanıklılık ve Demografik Değişkenlere Göre İncelenmesi”, 15. Eğitim Bilimleri Kongresi, 13-15 Eylül, Muğla.

Bailey, Richard (2006), "Physical Education and Sport in Schools: A Review of Benefits and Outcomes”, Journal of School Health, 76(8), ss. 397-401. 
Basım, Nejat ve Çetin, Fatih (2011), "Yetişkinler için Psikolojik Dayanıklılık Ölçeği'nin Güvenilirlik ve Geçerlilik Çalışması”, Türk Psikiyatri Dergisi, 22(2), ss. 104-114.

Bülbül, Alpay (2015), "Tenis ve basketbol sporcularının psikolojik dayanıklılık seviyelerini inceleme ve karşılaştırılması", Gedik Üniversitesi Sağlık Bilimleri Enstitüsü, Hareket ve Antrenman Bilimleri ABD, İstanbul.

Chan, David W. (2003), "Hardiness and its role in the stress-burnout relationship among prospective Chinese teachers in Hong Kong”, Teaching and Teacher Education, 19, ss. 381-395.

Crowley Barbara J, Hayslip Bert ve Hobdy Juliann (2003), "Psychological hardiness and adjustment to life events in adulthood", Journal of Adult Development, 10(4), ss. 237-248.

Dishman Rod K, Hales Derek P, Pfeiffer Karin A, Felton Gwen A, Saunders Ruth, Ward Dianne S, Dowda Marsha ve Pate Russell R (2006), "Physical Self-Concept And Self-Esteem Mediate Cross-Sectional Relations of Physical Activity And Sport Participation With Depression Symptoms Among Adolescent Girls”, Health Psychology, 25(3), ss. 396-407.

Doğan, Tayfun (2015), “Kısa Psikolojik Sağlamlık Ölçeği’nin Türkçe uyarlaması: Geçerlik ve güvenirlik çalışması", The Journal of Happiness \&Well-Being, 3(1), ss. 93-102.

Duman, Savaş ve Kuru, Emin (2010), “Spor Yapan Ve Spor Yapmayan Türk Öğrencilerin Kişisel Uyum Düzeylerinin Belirlenmesi ve Karşılaştırılması", Niğde Üniversitesi Beden Eğitimi ve Spor Bilimleri Dergisi, 4(1), ss. 18-26.

Garmezy, Norman (1993), “Children İn Poverty: Resiliency Despite Risk", Psychiatry, 56 (1), ss. 127-136.

Güngörmüş Kübra, Okanlı Ayșe ve Kocabeyoğlu Tuğçe (2015), "Hemşirelik Öğrencilerinin Psikolojik Dayanıkılıkları ve Etkileyen Faktörler", Psikiyatri Hemşireliği Dergisi, 6(1), ss. 9-14.

Harrisson Madelaine, Loiselle Carmen G, Duquette Andre ve Semenic Sonia E (2002), "Hardiness, work support and psychological distress among nursing assistants and registered nurses in Quebec", Journal of Advanced Nursing, 38(6), ss. 584-591. 
İlhan, Aydın (2017), "Egzersiz Katılımcılarının Psikolojik Dayanıklılık, Optimal Performans Duygu Durumu ve Güdülenme İliş kisi”, (Doktora Tezi), Ege Üniversitesi Sağl1k Bilimleri Enstitüsü, Sporda Psiko Sosyal Alanlar Anabilim Dalı, İzmir.

Judkins Sharon ve Rind Raedel (2005), "Hardiness, Job Satisfaction And Stress Among Home Health Nurses”, Home Health Care Management And Practice. 17, ss. 113-118.

Kayacı, Ümre (2014), “Üniversite Öğrencilerinin Psikolojik Doğum Sıraları ve Sosyal İlgi Düzeylerinin Psikolojik Dayanıkılık Düzeylerini Yordamadaki Rolünün İncelenmesi”, Yüksek lisans Tezi, Gazi Üniversitesi Eğitim Bilimleri Enstitüsü, Ankara.

Khan Zamirullah, Ali Anwar ve Mumtaz Naseem A. (2016), "Mental Toughness of different levels of Basketball players: A study", International Research Journal of Multidisciplinary Studies, 2(6), ss. 1-4.

Kimhi Shaul, Goroshit Marina ve Eshel Yohanan (2013), "Demographic variables as antecedents of Israeli community and national resilience", Journal of Community Psychology,41(5), ss. 631-643.

Klag, Stefanie ve Bradley, Graham (2004), "The Role Of Hardiness İn Stress And IIllness: An Exploration Of The Effect Of Negative Affectivity And Gender”, British Journal Of Health Psychology, 9, ss. 137-161.

Kumar, Amit (2016), “A study on mental toughness and sports competition anxiety for male and female basketball players”, International Journal of Physical Education, Sports and Health, 3(2), ss. 379-381.

Kumar Sunil, Singh Suhindar N ve Mitra, Santu (2016), “Comparison of mental toughness between male and female volleyball players of 12th south Asian games”, International Journal of Applied Research, 2(6), ss. 268270.

Küçük, Veysel ve Koç, Harun (2004), "Psiko-Sosyal Gelişim Süreci İçerisinde İnsan ve Spor İliş kisi”, Dumlupınar Üniversitesi Sosyal Bilimler Dergisi, 10, ss. 131-141.

Maddi, Salvatore R. ve Khoshaba, Deborah M. (1994), "Hardiness And Mental Health”, Journal of Personality Assesment, 63(2), ss. 265-274.

Maddi, Salvatore R, Khoshaba, Deborah M, ve Pammanter, Arthur (1999), "The Hardy Organization: Success By Turning Change To Advantage”, Consulting Psychology Journal, 51, ss. 117-124. 
Nicholls Adam R, Morley Dave, ve Perry John L. (2016), “Mentally tough athletes are more aware of unsupportive coaching behaviours: Perceptions of coach behaviour, motivational climate, and mental toughness in sport”, International journal of Sports Science \& Coaching, 11(2), ss. 172-181.

Özer, Melek ve Karabulut, Özlem Ö. (2003), "Yaşlılarda yaşam doyumu”, Geriatri, 6(2), ss. 72-74.

Reddy R.C. ve Berhanu Theodros (2016), “Mental toughness in sport: In case of Mekelle university sport teams”, International Journal of Applied Research, 2(3), ss. 1-3.

Salar Burcu, Hekim Mesut ve Tokgöz Mehmet (2012), “15-18 Yaş Grubu Takım ve Ferdi Spor Yapan Bireylerin Duygusal Durumlarının Karşıllaştırılması", Mehmet Akif Ersoy Üniversitesi Sosyal Bilimler Enstitüsü Dergisi, 4(6), ss. 123-135.

Sezgin, Ferudun (2009), “Relationships between teacher organizational commitment, psychological hardiness and some demographic variables in Turkish primary schools”, Journal of Educational Administration, 47, ss. 630-651.

Smith Bruce W, Dalen Jeanne, Wiggins Kathryn, Tooley Erin, Christopher Paulette \& Bernard Jennifer (2008), “The Brief Resilience Scale: Assessing the Ability to Bounce Back", International Journal of Behavioral Medicine, 15, ss. 194-200.

Solomon, Gloria B. (2015), "Mental toughness among college athletes", Journal of Applied Sports Science, 5(3), ss. 171-175.

Şahin, Mustafa, Yetim Azmi A ve Çelik Akın (2012), "Psikolojik Sağlamlığın Gelişiminde Koruyucu Bir Faktör Olarak Spor ve Fiziksel Aktivite”, The Journal of Academic Social Science Studies, 5(8), ss. 373-380.

Terzi, Şerife (2008), “Üniversite Öğrencilerinin Psikolojik Dayanıklılıkları ve Algıladıkları Sosyal Destek Arasındaki İliş ki”, Türk Psikolojik Danışma ve Rehberlik Dergisi, 29(3), ss. 1-11.

Vanderbilt-Adriance, Ella (2001), "Protective Factors and The Development of Resilience Among Boys From Low-İncome Families", Unpublished Master's Thesis. University Of Pittsburg, Pittsburg. 